DOI: $10.17516 / 1997-1370-0745$

УДК 342.8

\title{
Law and Digitalization:
}

\section{Some Academic Illusions and Practical Issues}

\author{
Ivan V. Leksin* \\ Lomonosov Moscow State University \\ Moscow, Russian Federation \\ Siberian Federal University \\ Krasnoyarsk, Russian Federation \\ Academy of Management of the Ministry of Internal Affairs of Russia \\ Moscow, Russian Federation
}

Received 02.09.2020, received in revised form 19.04.2021, accepted 27.04.2021

\begin{abstract}
The article analyzes two interrelated issues: the influence of digitalization upon the key phenomena that the legal theory deals with and the degree to which digitalization of actual processes reflects in the construction of the legislative provisions. The author examines the body of recent papers on these issues and the content of the Russian electoral and referendum legislation affected by the digitalization processes. He criticizes the unduly broad approach to understanding digitalization the Russian legal scholars tend to use and questions the applicability of the respective word to the most important legal phenomena. Above all, it comes necessary that the law can lend itself to digitization, while by no means it can be digitalized. Among the practical challenges the author emphasizes the need to rethink or redesign the structure of the usual legal relations exposed to the digital context. Vocabulary update and other superficial amendments to the existing legal provisions are quite an insufficient answer to this challenge. A careful and sophisticated revision of legislative construction is required in order to deal with the digitization issues, while currently the mentioned need often remains without due attention of the lawmakers.
\end{abstract}

Keywords: law, legislation, electoral and referendum law, digitalization, digitization, law-making, law application.

Research area: law.

Citation: Leksin, I.V. (2021). Law and digitalization: some academic illusions and practical issues. J. Sib. Fed. Univ. Humanit. Soc. Sci., 14(5), 602-610. DOI: 10.17516/1997-1370-0745.

\footnotetext{
(C) Siberian Federal University. All rights reserved

* Corresponding author E-mail address: leksin@spa.msu.ru ORCID: 0000-0002-5635-820X
} 


\title{
Право и цифровизация: \\ некоторые теоретические иллюзии и практические проблемы
}

\author{
И.В.Лексин \\ Московский государственный университет имени М. В. Ломоносова \\ Российская Федерация, Москва \\ Сибирский федеральный университет \\ Российская Федераиия, Красноярск \\ Академия управления Министерства внутренних дел Российской Федерачии \\ Российская Федерачия, Москва
}

\begin{abstract}
Аннотация. Статья посвящена двум взаимосвязанным проблемам: корреляции цифровизации с ключевыми правовыми явлениями, которыми оперирует юридическая теория, и степени отражения цифровизации фактических процессов в законодательных конструкциях. Автор проводит разбор содержания опубликованных по данной проблематике научных работ и положений российского избирательного и референдумного законодательства, сопряженных с цифровизационными процессами. Высказываются критические соображения в отношении чрезмерно широкого понимания цифровизации, свойственного отечественной юриспруденции, и подвергается сомнению применимость термина «цифровизация» к наиболее значимым правовым явлениям. Прежде всего следует признать, что само право поддается лишь оцифровыванию, но никак не цифровизации. Среди практических вызовов автор выделяет потребность в переосмыслении и переработке юридических конструкций привычных отношений с учетом цифровизационного контекста. Регулирование поведения, осуществляемого в цифровом формате, требует не просто новой терминологии и иных косметических исправлений законодательных положений, но взвешенного и тщательного пересмотра таких конструкций, чему законодатель далеко не всегда уделяет должное внимание.
\end{abstract}

Ключевые слова: право, законодательство, избирательное и референдумное право, цифровизация, оцифровывание, правотворчество, правоприменение.

Научная специальность: 12.00.00 - юридические науки.

\section{Introduction}

The phenomenon of digitalization keeps the scholars' and experts' attention for quite a while and in so doing gradually expands the research realm suited for using the corresponding term. Having emerged as the technological notion describing the economic processes, digitalization is currently a particular passion of the scientists conducting researches in the social sphere, in public administration and public policy, and in law as well. However, the analysis of papers being published by the Russian-speaking authors shows a considerable lack of un- derstanding of the meaning of this notion. Unfortunately, this inadvertence is quite common among Russian lawyers.

As a result, there exists a huge body of academic papers that are outwardly devoted to digitalization and law, but actually do not deal either with digitalization, or with the legal issues of digitalization. At the same time, many conceptual issues of legal manifestation of digitalized social practices remain under-explored. In the practical field the lack of conceptualization is perceptible as well. This lack leads to oversimplification of the changing re- 
ality manifested, inter alia, in the tendency to keep using the old-fashioned legal constructions with the superficial terminological modifications.

\section{Theoretical Framework}

The impact of digitalization upon the sphere of law is an accomplished fact recognized by the legal science (Franceschi, 2016; Frankel \& Gervais, 2014; Grundmann, 2018). As their foreign colleagues, Russian scholars agree unanimously that digital innovations affect law-making and application of law almost inevitably (Pashentsev, 2018). However, despite the relative youth of the phenomena called digitalization, the concept of the latter failed to remain solid on a global scale. Unfortunately, that is to a great extent the consequence of superficial acquaintance of the non-English-speaking authors with the origins of the respective term. Particularly, the Russian calque of the English noun "digitalization" sounds relative to every matter that is digital or is digitized. Within the economic science the scholars are quite familiar with the differences between digitizing and digitalizing, of course. Yet, Russian non-economists often use the word "digitalization" instead of "digitization" to describe the conversion of information into digital format.

It may come as a surprise to Russian lawyers that it is the Russian legal science, along with the Chinese one $(\mathrm{Qu}, 2013)$, that appears to be the leader in discovering or, rather, fabricating the phenomenon of the so-called digitalization of law (Anisimova, 2019; Kornev, 2019; Nikolaev, 2019; Poliakova, Minbaleev, \& Boichenko, 2019; Turitsyn, 2019). Notwithstanding this terminological misapprehension, among the recently published papers one can discover thorough analysis of the legal implications caused by digitalization spreading through manufacturing, various business processes, and administrative activities (Khabrieva, 2018; Khabrieva, Chernogor, 2018; Talapina, 2018; Mal'ko, Soldatkina, 2019; Pashentsev, 2019a).

Thus, the Russian scholars' views on the essence of digitalization and on its practical role are homogeneous neither throughout the science field, nor within a single branch of science. Below we shall see if these predicaments can be overcome.

\section{Statement of the Problem}

As stated above, in the Russian-language papers devoted to interconnections between law and digitalization one can often see the confusion of essentially different notions that ought to be designated by different terms. Hence, the questions that need to be answered first of all are what legal phenomena can be digitalized, and to what degree.

Thereupon more practical issues can be addressed. Namely, it seems useful to determine what manifestations of digitalization can be observed in the legal reality. Actually, a huge body of papers published in two last decades (Pavlushkin, Postnikov, 2009; Ovchinnikov, Antonov, 2014; Vasil'eva, 2019) touch upon this issue. However, they are basically focused on the additional subject matters that are in need of legal framework, on the content of legal provisions being designed to handle this need, and on the new procedures of law-making and of implementing legal provisions. The scholars' enthusiasm about upcoming novelties in law is explainable, reasonable, and acceptable. Yet, currently they pay almost no attention to the need for altering the construction of typical legal relations that we are well accustomed to. Such a need is surely not pressing in every case, but this problem ought to be recognized as well.

This article does not claim to solve these problems once and for all, of course. However, it aspires to detect the imperfections of the legal theory regarding digitalization issues, to analyze the compliance of the standing legal provisions with the practical restructuring of the corresponding legal relations, and to start filling some of the revealed gaps.

\section{Theoretical Discussion}

In view of the aforesaid, the sphere of the correct use of the word "digitalization", as far as the legal phenomena are being affected, requires a sort of clarification. There are significant doubts about the applicability of this term to many of such phenomena. 
The first of these phenomena is the law itself. The English-speaking author would hardly discuss digitalization of law, but would rather prefer to talk about digitalization in law (Radvan, 2020). A similar picture can be observed in German, French, Italian, or Spanish academic papers on that subject, that usually do not contain the terms "Rechtsdigitalisierung", "numérisation du droit", "digitalizzazione dei diritti", or "digitalización del derecho", respectively. Exceptions can be found in journalistic articles and in foreign-language journals quartered in the post-Soviet countries (Gabisonia, 2020: 35).

As stated above, the Russian scholars often see the law itself as the matter being digitalized. Speaking about the digitalization of law and, sometimes, even of the system of law (Karzhia, Makarenko, \& Sergin, 2019) the authors unconsciously replace either digitalization with the development occurring in the digital era, or the law with the processes being governed by law, or both notions simultaneously. However, such omissions are not a general rule. It would not be just to say that the entire research community confuses digitalization with digitization, or does not see the difference between digitalization of law and digitalization of social processes and business activities governed by law. Quite a lot of legal scholars give an accurate account of the links between the law and digitalization. Particularly, understanding digitalization as a phenomenon that is only capable of forming the context (Mal'ko, Soldatkina, 2019; Sidorenko, Arx, 2020) or the challenges (Pashentsev, 2019a) for legal development is rather common, while some authors ask themselves if the jural activities are being digitalized, or solely digitization of legal tasks may be observed (Krainova, 2019).

The second improper subject of digitalization is a legal norm (or a legal rule). It can be neither digital nor non-digital. Its textual content can be digitized, of course, but this does not affect the essence of the rule itself.

Strictly speaking, the sources of law cannot be digital or non-digital as well. However, the means of delivering their content to the destination users can be divided into digital and non-digital. The most convenient subjects for digitalization here are the processes of promulgation and systematization of legal sources.

The digitalization of legal relations per se is also highly questionable. Some activities, sequences of actions, processes of interaction can be digitalized, but these are considered by the legal theory either as the objects of legal relations, or as their content. Yet, the actual social relations can be named the subjects of digitalization (Pashentsev, Alimova, 2019) more soundly.

Another doubtful issue is digitalization of law-making. The scholars tend to use this collocation metaphorically, in a way. In actual fact digital law-making mentioned by the authors (Kurakina, Kruglov, 2019; Pashentsev, 2019b) means the support of computer-based systems and other digital technologies to law-making and digitization of the statutes and bylaws, but not digitalized law-making per se.

The application of law, in the strict sense, cannot be digitalized as well. Even the seemingly suitable cases appear to be invalid after consideration. For instance, providing public services in electronic form implies digitalization of the social interaction, not of the legal one. Moreover, in this case the digital format is not the feature of the services themselves, but of the means and of the results of providing these services only.

Legal liability as a theoretical phenomenon and other forms of legal coercion can hardly be the subjects of digitalization, too. The latter remains rather the practical context of the liability than its inner feature. For instance, mailing digital copies of law enforcement decisions is quite a common practice. It comes as no surprise as well that registration, stocking and storing case material can be digitalized. The proceedings on cases of some categories, especially related to road safety, have already been digitalized to a considerable degree. Currently not only the factual situations are to be recorded in an automatic mode, but also their qualification as administrative offenses and the identification of the offender are to be done by the software. In the given circumstances officers operate rather like technicians than like decision-makers, and it is plausible to assume 
that the scope of such operations will continue broadening.

The list of the phenomena that the authors unreasonably believe to undergo digitalization can be prolonged. For instance, among these phenomena legal profession can be met (Gaivoronskaia, Karimova, 2020), although it cannot be recognized as a process or as an activity. However, unlike legal profession as an occupation, legal education as a process can definitely be digitalized to a certain extent (Smith, Banet, \& Romera, 2019).

\section{Inertness of Law-Making vs Digitalization}

As one can notice, Russian legal science is quite active in reasoning on the digitalization issues. However, declarative statements about the obvious challenges of digitalization tend to prevail over expert recommendations and legislative initiatives. Particularly, the need to rethink or redesign the structure of usual legal relations coming under the pressure of the digital context often remains without due attention.

This lack of due concern manifests itself in the dynamics of legislative provisions devoted to various issues. Among them is the election and referendum campaigning. The latter had undergone a severe transformation under the digital technologies influence during the last decades. Quite a long time the legislator simply did not notice the actual changes in the practice of election and referendum campaigns. Yet, having noticed these changes, he considered it possible to reduce the amendments to cosmetic additions to the existing legal provisions. As a result, the legislative acts on elections and referenda started mentioning the Internet and other information and telecommunication networks, as well as online publications. However, neither new forms of political advertising were provided for, nor the design of the existing ones had been changed since the adoption of the first Federal law "On the Basic Guarantees of the Russian Citizens' Electoral Rights and the Right to Participate in Referenda" in 1994. Particularly, the legislation does not distinguish between non-digital and digital formats for the production, distribution, and publication of the campaign texts, audio and video. This reveals a rather unsophisticated view of the lawmak- er on the digital technologies. However, legal relationships regarding non-digital or digital formats of campaigning activities are constructively different from each other, and the compatibility of the digital format of campaigning with the pre-digital one as the issues governed by the uniform legal rules is highly doubtful.

First, the legislator did not distinguish printed matters related to the election and referendum campaigns from the digital ones. On the one hand, such unification may be justified, as far as the same layout may serve as the basis for both print and digital media publications. But now as well as before, the statutes governing electoral and referendum campaigns do not explain what a political advertising matter is. The electoral and referendum laws merely read that these matters can be either printed or so-called audiovisual or other, thus leaving the meaning of the very advertising matter unclear. Meanwhile, this meaning is vitally important for the competing nominees and political parties, as well as for the officers of the election commissions and of other governmental bodies, as far as the laws require that the copies of the advertising matters be provided to the respective election commission. However, a digital advertisement frequently comprises a sequence of files or file folders that only look like a solid matter to the user. The legislation ignores that fact totally, setting no guidelines for identifying the advertising matter. Under current legislation there are equal grounds to believe that a digital advertising matter is either a single file, or a webpage, or a website. Given that this issue is not clarified it is quite uneasy, for instance, to meet the demand that every printed and the so-called audiovisual advertising matter contains the information on the manufacturer and other technical data. Besides, amazingly, the statutes providing for the election and referendum campaigns require that this data include the number of the copies of every advertising matter. These provisions always drive the electoral campaigns managers to a nonplus in case of producing digital matters.

Second, digital and non-digital formats of the publications can imply significant differences in the legal construction of producing and reproducing the respective matters. In par- 
ticular, producing non-digital matters usually falls into two stages, namely, designing and manufacturing. Within each of the latter specific parties and separate outputs can be observed. Production of a digital matter can also be divided into two stages. The first one remains the same in general. It implies typesetting, text editing, recording and editing graphic, audio and video files. Yet, the second stage is quite different as compared with one referring to the non-digital format. It consists of filling the Internet pages or websites with the files created at the first stage. The jobs at the both stages as the digital format is concerned are usually ordered to a single executor. Thus, the structure of legal relations regarding producing and reproducing the campaign matters in the printed format is not identical with the structure of legal relations concerning the digital format of the campaign matters. This fact requires the diversification of the legal provisions governing the election and referendum campaigns carried out in the digital and non-digital formats.

Third, the provisions describing the election and referendum campaigning activities do not always reflect the nature of campaigning with the support of digital technologies adequately. In particular, the very legislative definition of the political advertising campaign as an activity carried out by the citizens and social associations seems to be utterly artificial, especially in respect of campaigning via websites. In this case the persons that the advertising actions are imputed to by Federal law No. 67-FZ dd. 12 June 2002 "On the Basic Guarantees of the Russian Citizens' Electoral Rights and the Right to Participate in Referenda", as well as by other federal and regional statutes on the election and referendum issues, may actually execute no legally significant actions at all during the entire campaign period. Strictly speaking, the actions required within this period will only be the opening and closing the access to the websites. Technically, such actions should be attributed either to the website owner, or to the system manager. Considering the above, it seems to be appropriate to provide either that election and referendum campaigning through the website constitutes an activity classified separately from the political advertising itself as the legislation sees it, or that the citizens and social associations are not the only participants of political advertising. Recognizing legal entities and their representatives as such participants would increase the pertinence of the electoral and referendum legislation with reference to the traditional means of political advertising as well. For instance, the mentioned reduction of the political advertising campaign actors to the citizens and social associations does not seem quite relevant in case of using print media or television and radio broadcasting.

Fourthly, the political advertising campaign timing requires special provisions in relation to the Internet publications. For example, the legislative requirement to stop this campaign at 00 hours local time the day before the election or referendum day is meaningless in respect of the Internet. Given that a single constituency covers several time zones frequently, a literal understanding of this provision actually implies that it is the Internet provider who should close access to some content for the users located within a certain area, as far as an ordinary website manager would hardly be able to filter the users requests effectively so that the voters living in a certain zone were not exposed to the website content for an extra couple of hours. In order to avoid these difficulties and mistakes it would be reasonable to provide that in case of holding an election or a referendum in several time zones the political advertising campaign should be ended in the whole constituency simultaneously.

Fifthly, the legislative ban for including commercial advertising into the political one remains intact despite its ambiguity evolving from the digital format (Goncharov, Goncharenko, Kabyshev et al., 2005; Goncharenko, Ermakov, Kabyshev et al., 2009). This ban was quite implementable in non-digital context, but the lawmaker overlooked the necessity to modify it by indicating the permissible proximity of the commercial advertisements to the political ones within a website being used for different purposes and serving the interests of different parties.

The mentioned examples are not the only illustrations of the lawmakers' backwardness in following the digitalized reality of the elec- 
tion and referendum campaigning, of course. A far greater number of the non-settled issues can be discovered outside the electoral and referendum legislation, within such branches of law dealing with the technological advances as administrative law, information law (that contains provisions governing data management), financial law, power engineering law, education law, etc.

Hence a careful and sophisticated revision of legislative construction is required in order to deal with these issues. With regard to the electoral and referendum law this revision can proceed in one of the two following directions. First, the lawmaker can fractionalize the legislative provisions so as to design separate regimes for campaigning in non-digital and digital formats. Second, the lawmaker can do almost the reverse. Abandoning the detailed regulation of the campaigning procedure with a focus on protective provisions would reduce the need for bifurcation of the legal regimes related to the mentioned formats, as well as of the respective terminology.

\section{Conclusion}

Thus, quite few of the phenomena that the legal theory deals with can become digital or amenable to digitalization. In most of its practical manifestations digitalization is only the issue that these phenomena have to face with. It implies more extensive and sophisti- cated regulation, but the essence of law itself is being neither damaged, nor improved thereby. The content of law changes in the digital age, of course. However, this change is not the digitalization of law, but the reflection of digitalization of the socio-economic and other actual processes in the content of law. The law-making experiences transformation as well. However, digital technologies play only supplementary role in the law-making process. They lighten the paperwork greatly, thus producing the illusion of digitalizing the very law-making. As compared with the latter, the application of law is a much more promising subject of digitalization. However that may be, only actual business and administrative processes and activities remain the incontrovertible subjects of the latter at the given stage of the technological development and in present condition of the legal thought.

At the practical level problems of the other kind can be observed. The lawmaker usually seeks to follow the simplest path of expanding the existing legal constructions designed for the non-digital context to the reality generated by the digitalization processes. Meanwhile, the need to revise the legal regulation in compliance with the peculiarities implied by the ongoing digitalization remains unsatisfied frequently. Such a revision requires fairly large patience and skills, but it is really necessary for keeping legal regulation relevant.

\section{References}

Anisimova, A.S. (2019). Pravovaia politika v sfere tsifrovizatsii prava [Legal policy in the field of digitalization of law]. In Pravovaia politika i pravovaya zhizn' [Legal policy and legal being], 3(76), $172-175$.

Franceschi, A. (Ed.), (2016). European Contract Law and the Digital Single Market: The Implications of the Digital Revolution. Intersentia. DOI: 10.1017/9781780685212.003

Frankel, S., Gervais, D. (Eds.). (2014). The Evolution and Equilibrium of Copyright in the Digital Age (Cambridge Intellectual Property and Information Law). Cambridge: Cambridge University Press. DOI: 10.1017/CBO9781107477179

Gabisonia, Z. (2020). Einige konzeptionelle Fragen in der rechtlichen Regelung des so genannten "intelligenten Vertrages" (Smart Contract). In Deutsch-Georgische Zeitschrift fur Echtsvergleichung, 3, 32-42.

Gaivoronskaia, Ia.V., Karimova, Iu.I. (2020). Tsifrovizatsiia iuridicheskoi professii: o riskakh i ugrozakh tsifrovizatsii rynka truda [Digitalization of the legal profession: on the risks and threats of digitalization of the labor market]. In Advances in Law Studies, 8(S), 55-63.

Goncharov, V.P., Goncharenko, P.A., Kabyshev, S.V., Leksin, I.V., Minkh, G.V., Orlova, E.M., Panferov, K.Iu., Chuchelina, N.N., Selkovskii, D.A., \& Shumilin, V.A. (2005). Pravovoe regulirovanie vyborov 
Prezidenta Rossiiskoi Federatsii [Legal regulation of the RF President election]. Moscow, Formula prava, $160 \mathrm{p}$.

Goncharenko, P.A., Ermakov, A.D., Kabyshev, S.V., Leksin, I.V., Maslov, A.V., Minkh, G.V., Chuchelina, N.N., Goncharov, V.P., Orlova, E.M., Panferov, K.Iu. (2009). Vybory Prezidenta Rossiiskoi Federatsii: iuridicheskoe rukovodstvo po izbiratel'nomu protsessu [The RF President election: legal guide to the electoral process]. Moscow, Formula prava, $438 \mathrm{p}$.

Grundmann, S. (Ed.). (2018). European Contract Law in the Digital Age. Intersentia. DOI: $10.1017 / 9781780686431$

Karzhia, A.A., Makarenko, G.I., \& Sergin, M.Iu. (2019). Sovremennye trendy kiberugroz i transformatsiia poniatiia kiberbezopasnosti v usloviiakh tsifrovizatsii sistemy prava [Modern trends of cyber-threats and transformation of the concept of cybersecurity in the conditions of digitalization of the system of law]. In Voprosy kiberbezopasnosti [Cybersecurity issues], 3(31), 18-23. DOI: 10.21681/2311-3456-2019-3-18-23

Khabrieva, T.Ia. (2018). Pravo pered vyzovami tsifrovoi real'nosti [Law facing the challenges of digital reality]. In Zhurnal rossiiskogo prava [Journal of Russian law], 9, 5-16.

Khabrieva, T.Ia., Chernogor, N.N. (2018). Pravo v usloviiakh tsifrovoi real'nosti [The law in the conditions of digital reality]. In Zhurnal rossiiskogo prava [Journal of Russian law], 1, 85-102.

Kornev, A.V. (2019). Digitalizatsiia prava: problemy i perspektivy [Digitalization of law: challenges and prospects]. In Aktual'nye problemy rossiiskogo prava [Current issues of Russian law], 6(103), 11-18. DOI: 10.17803/1994-1471.2019.103.6.011-018

Krainova, N.A. (2019). "Elektronnye vesy pravosudiia": tsifrovizatsiia protsessov ili otsifrovka zadach? ["Electronic Scales of Justice": Digitalization of Processes or Digitization of Tasks?]. In Kriminologia: vchera, segodnia, zavtra [Criminology: yesterday, nowadays, tomorrow], 1(52), 35-38.

Kurakina, S.I., Kruglov, D.N. (2019). O perspektivakh tsifrovogo pravotvorchestva [On the prospects of digital lawmaking]. In Gumanitarnye, sotsial'no-ekonomicheskie i obshchestvennye nauki [Humanities, social-economic and social sciences], 10, 168-171. DOI: 10.23672/SAE.2019.10.39045

Mal'ko, A.V., Soldatkina, O.L. (2019). Prioritety rossiiskoi pravovoi politiki i izmeneniia prava v usloviiakh tsifrovizatsii [Priorities of Russian legal policy and changes in law in the context of digitalization]. In Zhurnal rossiiskogo prava [Journal of Russian law], 9, 5-19.

Nikolaev, A.I. (2019). Voprosy tsifrovizatsii prava v sovremennoi iuridicheskoi doktrine [Digitalization of law in modern legal doctrine]. In Vestnik Moskovskogo gorodskogo pedagogicheskogo universiteta. Seriia "Iuridicheskie nauki" [Vestnik of Moscow City University. "Legal Sciences" Series], 4(34), 44-48.

Ovchinnikov, V.A., Antonov, Ia.V. (2014). Pravovye istoki elektronnogo golosovaniia v sisteme elektronnoi demokratii [Legal sources of electronic voting in the system of electronic democracy]. In Gosudarstvennaia vlast' i mestnoe samoupravlenie [State power and local self-government], 7, 40-45.

Pashentsev, D.A. (2018). K voprosu o vliianii tsifrovykh tekhnologii na pravotvorchestvo i pravoprimenenie (postanovka problemy) [On the influence of digital technologies on law-making and law enforcement (problem statement)]. In Rossiiskoe gosudarstvovedenie [Russian state studies], 4, 131-137.

Pashentsev, D.A. (2019a). Rossiiskaia zakonotvorcheskaia traditsiia pered vyzovom tsifrovizatsii [Russian legislative tradition before the challenge of digitalization]. In Zhurnal rossiiskogo prava [Journal of Russian law], 2, 5-13.

Pashentsev, D.A. (Ed.) (2019b). Tsifrovizatsiia pravotvorchestva: poisk novykh reshenii [The Digitalization of law-making: the search for new solutions]. Moscow, INFRA-M, $234 \mathrm{p}$.

Pashentsev, D.A., Alimova, D.R. (2019). Novatsii pravotvorchestva v usloviiakh tsifrovizatsii obshchestvennykh otnoshenii [Innovations of law-making in the conditions of digitalization of public relations]. In Gosudarstvo i pravo [State and law], 6, 102-106.

Pavlushkin, A.V., Postnikov, A.E. (2009). Pravovoi mekhanizm distantsionnogo elektronnogo golosovaniia (analiz vozmozhnoi modeli) [Legal mechanism of distance electronic voting (feasible model analysis)]. In Zhurnal rossiiskogo prava [Journal of Russian law], 11, 5-13.

Poliakova, T.A., Minbaleev, A.V., \& Boichenko, I.S. (2019). Kontseptual'nye podkhody k pravovomu regulirovaniiu informatsionnoi bezopasnosti $\mathrm{v}$ usloviiakh tsifrovizatsii i transformatsii prava [Conceptual 
approaches to the legal regulation of information security in the conditions of digitalization and transformation of law]. In Vestnik UrFO. Bezopasnost'v informatsionnoi sfere [UrFR Newsletter. Information Security], 3(33), 64-68. DOI: 10.14529/secur190307

$\mathrm{Qu}, \mathrm{X}$. (2013). The Digitalization of Law. In Science of Law (Journal of Northwest University of Political Science and Law), 1.

Radvan, M. (2020). Guest Editor's Note on Digitalization in Law. In BRICS Law Journal, 7(2), 5-9. DOI: $10.21684 / 2412-2343-2020-7-2-5-9$

Sidorenko, E.L., Arx, P. (2020). Transformatsiia prava v kontekste tsifrovizatsii: v poiske prioritetov [Transformation of law in the context of digitalization: defining the correct priorities]. In Tsifrovoe pravo [Digital law journal], 1(1), 24-38. DOI: 10.38044/DLJ-2020-1-1-24-38

Smith, D.C., Banet, C., \& Romera, B.M. (2019). Teaching the Law of Energy Transition in the Era of Internationalisation and Digitalisation of Legal University Education: the Transatlantic University Collaboration in Climate Change and Energy Law (TUCCCEL) Programme. In Journal of Energy \& Natural Resources Law, 37: 4, 443-464. DOI: 10.1080/02646811.2019.1663048

Talapina, E.V. (2018). Pravo i tsifrovizatsiia: novye vyzovy i perspektivy [Law and digitalization: new challenges and prospects]. In Zhurnal rossiiskogo prava [Journal of Russian law], 2, 5-17.

Turitsyn, D.A. (2019). Dogovor kupli-prodazhi v usloviiakh tsifrovizatsii dogovornogo prava [Sale contract in the conditions of digitalization of contract law]. In Gumanitarnye, sotsial'no-ekonomicheskie $i$ obshchestvennye nauki [Humanities, social-economic and social sciences], 12, 309-312.

Vasil'eva, A.F. (Ed.) (2019). Pravo v informatsionnom obshchestve: transformatsiia ili modernizatsiia? [Law in a digital society: transformation or modernization?]. Krasnoyarsk, SibFU, 204 p. 